\title{
Research Square \\ Socioeconomic Difference of Husband's Involvement in Antenatal Care in Rural Indonesia
}

\section{Agung Dwi Laksono}

National Institute of Health Research and Development, The Ministry of Health, The Republic of Indonesia

\section{Ratna Dwi Wulandari ( $\triangle$ ratna-d-w@fkm.unair.ac.id)}

Faculty of Public Health, Universitas Airlangga, Surabaya, Indonesia

Mei Lina Fitri Kumalasari

Faculty of Psychology and Health, UIN Sunan Ampel, Surabaya, Indonesia

Ika Mustika

Faculty of Psychology and Health, UIN Sunan Ampel, Surabaya, Indonesia

\section{Ratu Matahari}

Faculty of Public Health, Universitas Ahmad Dahlan, Yogyakarta, Indonesia

\section{Research Article}

Keywords: husband's involvement, socioeconomic, maternal health, antenatal care, pregnancy care

Posted Date: November 24th, 2020

DOl: https://doi.org/10.21203/rs.3.rs-114665/v1

License: (c) (1) This work is licensed under a Creative Commons Attribution 4.0 International License.

Read Full License 


\title{
Socioeconomic Difference of Husband's Involvement in Antenatal Care in Rural Indonesia
}

\author{
Agung Dwi Laksono1, *Ratna Dwi Wulandari², Mei Lina Fitri Kumalasari², \\ Ika Mustika ${ }^{3}$, Ratu Matahari ${ }^{4}$ \\ ${ }^{1}$ National Institute of Health Research and Development, The Ministry of Health, The \\ Republic of Indonesia. \\ ${ }^{2}$ Faculty of Public Health, Universitas Airlangga, Surabaya, Indonesia. \\ ${ }^{3}$ Faculty of Psychology and Health, UIN Sunan Ampel, Surabaya, Indonesia. \\ ${ }^{4}$ Faculty of Public Health, Universitas Ahmad Dahlan, Yogyakarta, Indonesia \\ *Corresponding Author: Ratna Dwi Wulandari. ratna-d-w@fkm.unair.ac.id
}

\begin{abstract}
Background: To reduce maternal mortality, the Indonesian government campaigned for a health promotion program based on the family approach, namely "Suami Siaga" (Husband Alert). Study aims to analyze the effect of socioeconomic on the husband's involvement in ANC in rural Indonesia.

Methods: The study employed data from the 2017 IDHS. Samples of 7,156 respondents were obtained. Besides the socioeconomic, other variables analyzed in this study were age, education, occupation, and parity. The final stage was employed binary logistic regression.

Results: Families with the poorer socioeconomic status, the possibility of husbands being involved in ANC was 2.154 times compared to the poorest. Families with the middle socioeconomic status were more likely to have their husbands involved in ANC 2.785 times compared to the poorest. Families with a richer socioeconomic status were more likely to have their husbands involved in ANC 2.901 times compared to the poorest. Meanwhile, families with poorer socioeconomic status, the possibility of their husbands being involved in ANC was 5.299 times compared to the poorest. The results of this analysis inform that all socioeconomic statuses have a higher likelihood of husband involvement in ANC than the poorest families. The better the socioeconomic, the higher the possibility of the husband to be involved in ANC. Apart from socioeconomic, 3 other variables were also found as determinants of the husband's involvement in ANC in rural Indonesia, namely education, occupation, and parity.

Conclusions: The socioeconomic status was a determinant of the husband's involvement in ANC in rural Indonesia.
\end{abstract}

Keywords: husband's involvement, socioeconomic, maternal health, antenatal care, pregnancy care. 


\section{Introduction}

Maternal and child health is still an important concern for countries in the world, especially in poor and developing countries. Maternal health is also a gender issue globally $[1,2]$. One indicator of maternal health is the number of maternal deaths in a country. According to WHO data, as many as $94 \%$ of maternal deaths in the world occur in poor and developing countries [3].

As a developing country, Indonesia has a high maternal mortality rate (MMR). When compared to countries in Southeast Asia, the maternal mortality rate in Indonesia is in the second-highest place under Laos. According to the results of the 2015 SUPAS (Inter-Census Population Survey), the maternal mortality rate (MMR) in Indonesia is 305/100,000 live births. This number has decreased when compared to MMR in 2012, which was 359/100,000 live births [4]. Even though it has decreased, this figure is still far from the WHO target in Sustainable Development Goals 3, wherein 2030 it is expected that the MMR globally will be less than 70/100,000 live births [3].

The provision of quality health services to mothers is one of the steps that can be taken to reduce maternal mortality. Health services ranging from examinations of pregnant women/ANC, delivery assistance by trained health workers in health facilities, care for mothers and babies after delivery to care in case of complications. ANC is done at least 4 times during pregnancy [5]. This is done to provide protection for pregnant women and the fetus by early detection of risk factors, taking precautions, and treating complications of pregnancy early. The health status of pregnant women is very much determined by the ANC which is carried out by the mother in a health facility [6,7].

Unfortunately, not all mothers can perform ANC during pregnancy and delivery in health services. Previous research has shown that mothers living in most parts of Eastern Indonesia experience problems with access to health services. This can be seen from the low coverage of pregnancy visits, coverage of deliveries by trained health personnel, and the coverage of postnatal visits which have an impact on high maternal mortality in eastern Indonesia [8]. Lack of access to health services is due to several factors, including poverty, distance to health facilities, lack of information, inadequate health services, and local culture and beliefs $[3,9,10]$.

To reduce maternal mortality, the Indonesian government campaigned for a health promotion program based on the family approach, namely "Suami Siaga" (Husband Alert) in 1999. The "Husband Alert" program was interpreted as a technical step to protect family-based maternal health and safety. The program serves as an alert for husbands about emergency signs of pregnancy so that the delivery process to health services is not too late [11]. Besides, the government has also implemented the making pregnancy safer (MPS) program, which strengthens the role of families to protect mothers who give birth. Not only that, but the Indonesian government also launched a birth planning and complications prevention program which aims to increase the coverage of health services for pregnant women and babies through the active role of families and communities to plan safe delivery so that mothers can deliver healthy babies [12]. However, with these programs, the situation related to maternal mortality in Indonesia is still a problem, but at least the program can increase visits to ANC services [11].

Poverty is a fundamental problem for developing countries. Poverty is the root problem of poor maternal health status $[13,14]$. Previous studies have shown an influence between the wealth index and the use of ANC services. Mothers with a high wealth index were more likely to use ANC services than mothers with a lower wealth index [15]. Mothers who come from underprivileged families will find it difficult to pay for trained health workers in health services, so they will ask for help from traditional healers/non-medical [16,17]. As a result, if 
there are complications or complications during pregnancy and childbirth, mothers from poor families do not get optimal treatment.

The mother's ability to use ANC services cannot be separated from the influence of her family, especially her husband. Husbands have an important role in maternal health. Several studies have shown that the husband's involvement in maintaining maternal health will have an impact on good health status. Husbands play a role in providing material and emotional support to mothers in getting optimal health services, besides helping to overcome problems or obstacles in accessing health services [18]. The husband's support can be shown by providing nutritious food, healthy housing, and transportation to health service places [19,20].

Also, the husband's support by accompanying his wife during ANC can increase the husband's knowledge about safe pregnancy and childbirth and his readiness in the event of complications [21]. Husbands with good knowledge of health significantly influence the selection of health services and trained health personnel. As the head of the family, good knowledge will influence the decisions made regarding the reproductive health of the family $[16,22]$. When the mother experiences complications such as labor bleeding, the husband becomes the main decision-maker in seeking treatment. Quick and correct decisions will save the mother from death from postpartum hemorrhage [23]. The results of a study in Nigeria showed that the involvement of the husband in pregnancy and childbirth had an impact on complications experienced by the mother. This is due to the husband's lack of knowledge about maternal health, not accompanying ANC and childbirth, and inaccurate decision making when complications occur [19].

Several regions in Indonesia, such as West Nusa Tenggara, still find gender imbalances between men and women. Women are positioned as parties who have to give in and follow the actions of their husbands towards them. Husbands as decision-makers in the family result in mothers not getting the opportunity to make decisions even though it is related to their health [24]. In Javanese culture, from generation to generation a wife is taught to obey the husband's orders and not to fight. This teaching has been trusted by the community and has become part of the patriarchal culture that still exists today, especially in rural areas [25].

Seeing the importance of the husband's role as the head of the family and the main decision-maker in the family, it is necessary to have an active role for the husband in accompanying the mother during pregnancy and childbirth. However, several conditions cause the husband to not optimally accompany his wife. One of them is because of negative cultural or social views towards the husband who accompanies the mother to ANC as well as the stereotype of women and their roles [19]. On the other hand, the lack of economic conditions, as well as demands that require the husband to earn a living for the family, have resulted in the husband being unable to accompany the mother to do ANC. Based on this description, this study aims to analyze the effect of socioeconomic status on husband involvement in ANC in rural Indonesia.

\section{Materials and Methods}

\section{Data Source}

The study was conducted using secondary data from the 2017 Indonesian Demographic Data Survey (IDHS). In this study, the unit of analysis used was husbands with wives aged 1549 years old in rural Indonesia, who had a pregnancy in the last five years before the interview. With the stratification and multistage random sampling method, this study obtained a sample of 7,156 respondents from the 2017 IDHS. 


\section{Data Analysis}

The definition of husband's participation in this study is the respondent's acknowledgment of the husband's involvement in accompanying his wife during pregnancy examinations. Socioeconomic status is the respondent's recognition of the wealth quintile owned by a household. Household wealth is assessed based on the number and type of goods owned. The wealth that counts is television to bicycles or cars, and housing characteristics, such as sources of drinking water, toilet facilities, and the main building materials for the floor of the house. This score is calculated using principal component analysis. The national wealth quintile is compiled based on the household score for each person in the household and then divided by distribution into the same five categories, each accounting for $20 \%$ of the population [26].

Apart from socioeconomic status, other variables analyzed as independent variables were age group, education level, occupation type, and parity of wife. Age is the respondent's acknowledgment of her husband's last birthday. Age is grouped into 5 categories, namely $\leq 20$, 21-30, 31-40, 41-50, and > 50. The husband's education level is the respondent's recognition of the last level of education the husband passed. The husband's education level is divided into 4 criteria, namely no education, primary, secondary, and higher. The husband's occupation type is the respondent's recognition of the husband's type or field of work. Occupation type consists of 9 categories, namely did not work, professional/technical, managers/administrators, clerical, sales, services, agricultural-self employed, industrial worker, and others. The parity of wife is the respondent's acknowledgment of the number of living babies who have been born by his wife. Parity is divided into 3 criteria, namely primiparous $(<2)$, multiparous $(2-4)$, and grand multiparous (> 4).

There are two types of analysis used in this study. First, the bivariate test uses the chisquare test to analyze the relationship between the socioeconomic and other variables. Second, a multivariate test to see the association of the independent variable with the husband's involvement in ANC as the dependent variable. A multivariate test was employed binary logistic regression because of the nature of the dependent variable. All statistical analyzes were performed with the help of IBM Statistic SPSS 22 software.

\section{Results}

Table 1 shows descriptive statistics of the respondent by socioeconomic and other related variables. The information in Table 2 shows that all categories of socioeconomic status are dominated by the husbands involved in ANC visits. Based on the age group, all categories of socioeconomic status were dominated by husbands who were in the 31-40 age group. Based on the education level, all categories of socioeconomic status are dominated by husbands who have secondary education, except for the poorest husbands who are dominated by primary education husbands. 
Tabel 1. The descriptive statistics of the socioeconomic status of respondents in rural Indonesia $(n=7,156)$

\begin{tabular}{|c|c|c|c|c|c|c|c|c|c|c|c|}
\hline \multirow{3}{*}{ Variables } & \multicolumn{10}{|c|}{ Socioeconomic Status } & \multirow{3}{*}{$\mathbf{P}$} \\
\hline & \multicolumn{2}{|c|}{ Poorest } & \multicolumn{2}{|c|}{ Poorer } & \multicolumn{2}{|c|}{ Middle } & \multicolumn{2}{|c|}{ Richer } & \multicolumn{2}{|c|}{ Richest } & \\
\hline & $\mathbf{n}$ & $\%$ & $\mathbf{n}$ & $\%$ & $\mathbf{n}$ & $\%$ & $\mathbf{n}$ & $\%$ & $\mathbf{n}$ & $\%$ & \\
\hline Husband's Involvement & & & & & & & & & & & $* * * 0.000$ \\
\hline - No & 1376 & $46.4 \%$ & 450 & $25.9 \%$ & 247 & $20.3 \%$ & 149 & $18.3 \%$ & 44 & $10.3 \%$ & \\
\hline - Yes & 1587 & $53.6 \%$ & 1290 & $74.1 \%$ & 972 & $79.7 \%$ & 666 & $81.7 \%$ & 384 & $89.7 \%$ & \\
\hline Age & & & & & & & & & & & $* * 0.001$ \\
\hline$\bullet \leq 20$ & 31 & $1.0 \%$ & 12 & $0.7 \%$ & 9 & $0.7 \%$ & 7 & $0.9 \%$ & 1 & $0.2 \%$ & \\
\hline - 21-30 & 934 & $31.5 \%$ & 519 & $29.8 \%$ & 360 & $29.5 \%$ & 199 & $24.4 \%$ & 114 & $26.6 \%$ & \\
\hline - $31-40$ & 1330 & $44.9 \%$ & 831 & $47.8 \%$ & 570 & $46.8 \%$ & 413 & $50.7 \%$ & 209 & $48.8 \%$ & \\
\hline - $41-50$ & 564 & $19.0 \%$ & 340 & $19.5 \%$ & 248 & $20.3 \%$ & 183 & $22.5 \%$ & 88 & $20.6 \%$ & \\
\hline - $>50$ & 104 & $3.5 \%$ & 38 & $2.2 \%$ & 32 & $2.6 \%$ & 13 & $1.6 \%$ & 16 & $3.7 \%$ & \\
\hline Education level & & & & & & & & & & & $* * * 0.000$ \\
\hline - No education (ref.) & 117 & $3.9 \%$ & 14 & $0.8 \%$ & 14 & $1.1 \%$ & 5 & $0.6 \%$ & 2 & $0.5 \%$ & \\
\hline - Primary & 1433 & $48.4 \%$ & 589 & $33.9 \%$ & 310 & $25.4 \%$ & 119 & $14.6 \%$ & 41 & $9.6 \%$ & \\
\hline - Secondary & 1273 & $43.0 \%$ & 987 & $56.7 \%$ & 772 & $63.3 \%$ & 530 & $65.0 \%$ & 222 & $51.9 \%$ & \\
\hline - Higher & 140 & $4.7 \%$ & 150 & $8.6 \%$ & 123 & $10.1 \%$ & 161 & $19.8 \%$ & 163 & $38.1 \%$ & \\
\hline \multicolumn{12}{|l|}{ Occupation type } \\
\hline - Did not work (ref.) & 23 & $0.8 \%$ & 17 & $1.0 \%$ & 7 & $0.6 \%$ & 4 & $0.5 \%$ & 3 & $0.7 \%$ & \\
\hline - Professional/technical & 100 & $3.4 \%$ & 107 & $6.1 \%$ & 84 & $6.9 \%$ & 92 & $11.3 \%$ & 68 & $15.9 \%$ & $* * * 0.000$ \\
\hline - Managers and Administration & 23 & $0.8 \%$ & 11 & $0.6 \%$ & 12 & $1.0 \%$ & 23 & $2.8 \%$ & 18 & $4.2 \%$ & \\
\hline - Clerical & 63 & $2.1 \%$ & 62 & $3.6 \%$ & 65 & $5.3 \%$ & 73 & $9.0 \%$ & 74 & $17.3 \%$ & \\
\hline - Sales & 116 & $3.9 \%$ & 154 & $8.9 \%$ & 158 & $13.0 \%$ & 122 & $15.0 \%$ & 84 & $19.6 \%$ & \\
\hline - Services & 364 & $12.3 \%$ & 270 & $15.5 \%$ & 189 & $15.5 \%$ & 125 & $15.3 \%$ & 51 & $11.9 \%$ & \\
\hline - Agricultural-self employed & 1684 & $56.8 \%$ & 655 & $37.6 \%$ & 372 & $30.5 \%$ & 176 & $21.6 \%$ & 52 & $12.1 \%$ & $* * * 0.000$ \\
\hline - Industrial worker & 576 & $19.4 \%$ & 449 & $25.8 \%$ & 324 & $26.6 \%$ & 183 & $22.5 \%$ & 64 & $15.0 \%$ & \\
\hline - Other & 14 & $0.5 \%$ & 15 & $0.9 \%$ & 8 & $0.7 \%$ & 17 & $2.1 \%$ & 14 & $3.3 \%$ & \\
\hline Parity of wife & & & & & & & & & & & $* * * 0.000$ \\
\hline - Primiparous (ref.) & 814 & $27.5 \%$ & 561 & $32.2 \%$ & 421 & $34.5 \%$ & 236 & $29.0 \%$ & 128 & $29.9 \%$ & \\
\hline - Multiparous & 1743 & $58.8 \%$ & 1058 & $60.8 \%$ & 733 & $60.1 \%$ & 552 & $67.7 \%$ & 280 & $65.4 \%$ & \\
\hline - Grandemultiparous & 406 & $13.7 \%$ & 121 & $7.0 \%$ & 65 & $5.3 \%$ & 27 & $3.3 \%$ & 20 & $4.7 \%$ & \\
\hline
\end{tabular}

Note: ${ }^{*} \mathrm{p}<0.05 ;{ }^{* *} \mathrm{p}<0.01 ;{ }^{* * *} \mathrm{p}<0.001$ 
Based on occupation type, all categories of socioeconomic status are dominated by husbands who work in agricultural-self employed, except for the husband with the richest socioeconomic status. The richer husband was dominated by industrial workers, meanwhile, the richest husband was dominated by the husband with a job as sales. Based on parity, all categories of socioeconomic status are dominated by husbands who have multiparous wives.

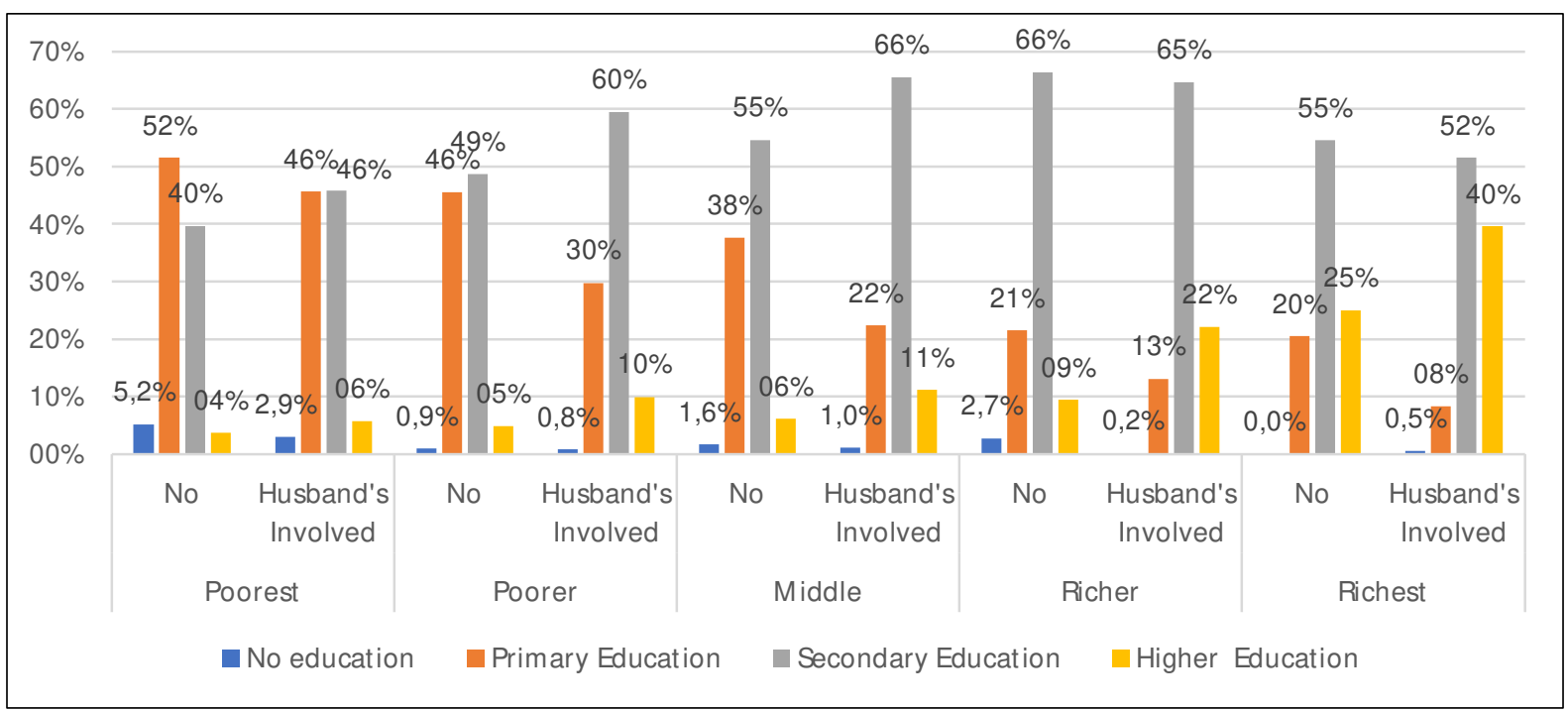

Fig. 1. Interaction diagram between wealth status, education level, and husband's involvement in ANC in rural Indonesia $(n=7,156)$

Figure 1 shows the interaction between 3 variables, namely wealth status, education level, and husband's involvement in ANC in rural Indonesia. The diagram illustrates that based on the wealth status and education level, it can be seen that the better the wealth status of a family is, the higher the percentage of husbands who have higher education are involved in their wife's ANC.

Table 2 shows the results of the binary logistic regression test to determine the variables that affect the husband's involvement in ANC in rural Indonesia. It can be seen that in families with a poorer socioeconomic status, the possibility of the husband being involved in ANC is 2.154 times compared to the poorest family (OR 2.154; 95\% CI 1.882-2.466). Families with the middle socioeconomic status are more likely to have their husbands involved in ANC 2.785 times than those of the poorest families (OR 2.785; 95\% CI 2.362-3.284). Families with the richer socioeconomic status were more likely to have their husbands involved in ANC 2.901 times than the poorest families (OR 2.901; 95\% CI 2.366-3.557). Meanwhile, families with poorer socioeconomic status, the possibility of their husbands being involved in ANC is 5.299 times compared to the poorest families (OR 5.299; 95\% CI 3.785-7.418). The results of this analysis inform that all socioeconomic statuses have a higher likelihood of husband involvement in wife's ANC. The better the socioeconomic status, the higher the possibility of a husband to be involved in the ANC process.

Apart from socioeconomic status, all tested variables were also found to have a significant effect on the husband's involvement, except for the age group. Based on the level of education, it was found that there was no difference between primary education and no education. Meanwhile, husbands with secondary education were 1.840 times more likely than no education husbands to be involved in ANC (OR 1.840; 95\% CI 1.302-2.600). Husbands with higher education have a probability of 3.090 times compared to no education husbands to be involved in ANC (OR 3.090; 95\% CI 2.039-4.684). These findings indicate that the higher the education level, the higher the chances of the husband being involved in his wife's ANC. 
Table 2. Binary logistic regression of husband's involvement in ANC in rural Indonesia $(n=7,156)$

\begin{tabular}{lcccc}
\hline & \multicolumn{4}{c}{ Husband's Involved in ANC visit } \\
\cline { 2 - 5 } \multicolumn{1}{c}{ Predictors } & Sig. & OR & $\begin{array}{c}\text { Lower } \\
\text { Bound }\end{array}$ & $\begin{array}{c}\text { Upper } \\
\text { Bound }\end{array}$ \\
\hline Socioeconomic status: Poorest (ref.) & - & - & - & - \\
Socioeconomic status: Poorer & $* * * 0.000$ & 2.154 & 1.882 & 2.466 \\
Socioeconomic status: Middle & $* * * 0.000$ & 2.785 & 2.361 & 3.284 \\
Socioeconomic status: Richer & $* * * 0.000$ & 2.901 & 2.366 & 3.557 \\
Socioeconomic status: Richest & $* * * 0.000$ & 5.299 & 3.785 & 7.418 \\
Age group: 20 (ref.) & - & - & - & - \\
Age group: 21-30 & 0.409 & 1.271 & .719 & 2.245 \\
Age group: 31-40 & 0.153 & 1.519 & .856 & 2.696 \\
Age group: 41-50 & 0.245 & 1.415 & .789 & 2.539 \\
Age group: > 50 & 0.554 & 1.216 & .637 & 2.322 \\
Education level: No education (ref.) & - & - & - & - \\
Education level: Primary & 0.172 & 1.271 & .901 & 1.795 \\
Education level: Secondary & $* * 0.001$ & 1.840 & 1.302 & 2.600 \\
Education level: Higher & $* * * 0.000$ & 3.090 & 2.039 & 4.684 \\
Occupation type: Did not work (ref.) & - & - & - & - \\
Occupation type: Professional/technical & $* * 0.008$ & 2.299 & 1.237 & 4.272 \\
Occupation type: Managerial and & 0.052 & 2.154 & 0.994 & 4.671 \\
Administration & & & & \\
Occupation type: Clerical & $* * 0.001$ & 2.852 & 1.502 & 5.414 \\
Occupation type: Sales & $* * 0.001$ & 2.919 & 1.590 & 5.359 \\
Occupation type: Services & $* * * 0.000$ & 2.894 & 1.599 & 5.236 \\
Occupation type: Agricultural - self & $* * 0.001$ & 2.569 & 1.437 & 4.595 \\
employed & & & & \\
Occupation type: Industrial worker & $* * 0.001$ & 2.688 & 1.495 & 4.830 \\
Occupation type: Other & $* 0.027$ & 2.540 & 1.109 & 5.817 \\
Parity: Primiparous (ref.) & - & - & - & - \\
Parity: Multiparous & $* * * 0.000$ & 0.569 & 0.494 & 0.657 \\
Parity: Grand multiparous & $* * * 0.000$ & 0.291 & 0.232 & 0.365 \\
\hline Note: & & & &
\end{tabular}

Note: $* \mathrm{p}<0.05 ; * * \mathrm{p}<0.01 ; * * * \mathrm{p}<0.001$.

Table 2 shows that based on occupation types, all husband's occupation types have a higher probability than husbands who do not work to be involved in ANC. Except for husbands who work in managerial and administration, what was found was no significant difference compared to husbands who did not work. Meanwhile, a husband who works as a professional/technical is 2.299 times more likely than a husband who does not work to be involved in ANC (OR 2.299; 95\% CI 1.237-4.272). Husbands who work as sales are 2.919 times more likely than husbands who do not work to be involved in ANC (OR 2.919; 95\% CI 1.590-5.236). Husbands who work as industrial workers are 2.688 times more likely than husbands who do not work to be involved in ANC (OR 2.688; 95\% CI 1.495-4.830).

The husband's involvement in wife's ANC was also found to be influenced by parity, the number of living children ever born by the wife. Husbands with multiparous wives were 0.569 times more likely than husbands with primiparous wives to be involved in ANC (OR $0.569 ; 95 \%$ CI $0.494-0.657$ ). Husbands with grand multiparous wives were 0.291 times more likely than husbands with primiparous wives to be involved in ANC (OR 0.291; 95\% CI 0.2320.365). This information shows that the greater the number of live children born to the wife, the lower the chances of a husband being involved in his wife's ANC. 


\section{Discussion}

The results of the analysis found that all socioeconomic statuses have a higher likelihood of husband involvement in accompanying wife's ANC compared to the poorest. The better the socioeconomic status, the higher the possibility of a husband to be involved in the ANC process. The high socioeconomic status makes it easy to get the best and complete ANC health facilities. They can pay for the consultation, medication, and other expenses associated with ANC services [27]. On the other hand, families with good socioeconomic status usually have their means of transportation, making it easier for pregnant women to come to the ANC service at any time [28].

The lower the family income, the lower the family activity in paying attention to the health of pregnant women. This is because meeting daily needs is more of a priority than the health of pregnant women [12]. This condition explains that the higher the household wealth, the more likely it is for the husband to accompany his wife in ANC services [29]. The results of this study are in line with the Obasohan study which analyzed barriers to accessing ANC services in the Wushishi Local Government Area. The results show that one of the factors affecting access to ANC services is the husband's finances. This condition is because the women there are still very dependent on their husbands. Therefore, if the husband's income is insufficient, pregnant women cannot access ANC services [30].

The results of the analysis information that the higher the education level, the higher the possibility of the husband being involved in his wife's ANC. Husbands with a high level of education will know more about the benefits of ANC. Besides, they also better understand the importance of their husband's presence in ANC services [20,31]. The results of this study are consistent with the results of the analysis conducted by Abdiana on the factors that influence ANC visits. Support from husbands with high levels of education is one of the factors determining the number of ANC visits [32]. The results of a study from Maken in 2017 also showed the same results. Husbands who have a higher level of education are better able to provide explanations and provide support to their wives to live a healthy life and to carry out antenatal care [33].

The results of the analysis inform that based on the occupation type, almost all husband's occupation types have a higher probability than husbands who do not work to be involved in ANC. This information shows that working will increase family income. Therefore, the working husband will have the financial capacity to pay for ANC services [34]. Family income and ANC fees are related to access to ANC services [5,29]. The results of previous research conducted by Othman on 460 mothers in the City of Sana'a, Yemen are the same as the results of the study in this study. Othman revealed that one of the factors that influenced mothers to make ANC visits was the husband's job [35]. A study conducted by Chanda on 4,475 mothers in Bangladesh also showed that there was a relationship between the husband's employment status and the involvement of the husband in finding a doctor for ANC services. Husbands who work, especially those with higher salaries, tend to look for the best doctors for their wives ' ANC services [36].

The findings of the study information that the more the number of live children born to the wife, the lower the chances of a husband being involved in his wife's ANC. This is due to the assumption that having so many children is sufficient to have knowledge and experience from pregnancy to childbirth. Therefore, they are less interested in coming to ANC services $[37,38]$.

The results of the previous study conducted by Rumaseaw showed the same results as this study. The more the number of children alive, the less the husband's support to come to ANC services also decreased. In the Rumaseaw study, respondents who were often accompanied by their husbands in ANC were those who had less than 2 children. This condition 
occurs because by having less than two children, the experience of pregnancy and childbirth is still lacking so that the husband participates in ANC to learn together about pregnancy and maintain the safety of his wife during pregnancy [12].

\section{Study Limitations}

This research was conducted by analyzing survey data with a quantitative approach so that the phenomena obtained was more superficial. This study cannot capture the phenomenon that is unique to the Indonesian context in the form of cultural influences and health beliefs on husband involvement in ANC. The results of previous studies found that there are cultural factors and health beliefs that play a role in the husband's involvement $[9,12]$. A deeper study with qualitative studies is needed to capture these cultural phenomena.

\section{Conclusions}

Based on the research results, it could be concluded that socioeconomic status was a determinant of the husband's involvement in ANC in rural Indonesia. The better the socioeconomic status, the higher the possibility of a husband to be involved in the ANC process. Apart from socioeconomic status, 3 other variables were also found as determinants of the husband's involvement in ANC in urban Indonesia, namely education level, occupation type, and parity of wife.

To increase the effectiveness of the "husband alert" campaign, the government needs to carry out accelerations targeting specific targets according to the analysis results in this study. The target for this specific rural area is husbands with characteristics of being poor, having low education, not working, and having primiparous wives.

\section{Declarations}

\section{Ethics approval and consent to participate}

The 2017 IDHS has passed the ethical test and received ethical clearance from the National Institute of Health Research and Development, the Indonesia Ministry of Health. The respondents' identities have all been deleted from the dataset. Respondents have provided written approval for their involvement in the study. Through the website: https://dhsprogram.com/data/new-user-registration.cfm. The researcher has obtained permission to use the data for this study.

\section{Consent for publication}

Consent of publication is "not applicable" to participants.

\section{Availability of data and materials}

Data cannot be shared publicly because of ethical restrictions prohibit public sharing of a data set. Data is available from the https://dhsprogram.com/data/new-user-registration.cfm by submitting an application to the ICF via the website. Other researchers will be able to access the data set in the same way as the authors, and the authors do not have special access rights that others do not have. 


\section{Competing interests}

The authors have declared that no competing interests exist.

\section{Funding}

The author(s) received no specific funding for this work.

\section{Authors' contributions}

ADL designed the study, collected data, undertook the analysis and wrote the manuscript; RDW assisted in study design, data collection, wrote and revised the manuscript; RM collected data and reviewed the manuscript. All authors reviewed and approved the final manuscript.

\section{Acknowledgements}

The author would like to thank the Inner City Fund for allowing the use of the 2017 IDHS.

\section{References}

1. Kurniati A, Chen C-MCM, Efendi F, Elizabeth Ku LJL-J, Berliana SMSM. Suami SIAGA: Male engagement in maternal health in Indonesia. Health Policy Plan. 2017;32: 1203-1211. doi:10.1093/heapol/czx073

2. Wulandari RD, Laksono AD. Determinants of knowledge of pregnancy danger signs in Indonesia. PLoS One. 2020;15: Article number e0232550. doi:10.1371/journal.pone.0232550

3. WHO. Maternal mortality. In: World Health Organization [Internet]. 2019. Available: https://www.who.int/news-room/fact-sheets/detail/maternal-mortality

4. the Minister of Health of the Republic of Indonesia. The 2019 Health Profile of Indonesia (Profil Kesehatan Indonesia 2019). Jakarta; 2020. Available: https://pusdatin.kemkes.go.id/resources/download/pusdatin/profil-kesehatanindonesia/Profil-Kesehatan-indonesia-2019.pdf

5. Laksono $\mathrm{AD}$, Rukmini $\mathrm{R}$, Wulandari RD. Regional disparities in antenatal care utilization in Indonesia. PLoS One. 2020;15: e0224006. doi:10.1371/journal.pone.0224006

6. Cameron L, Suarez DC, Cornwell K. Understanding The Determinants of Maternal Mortality: An observational Study Using The Indonesian Population Census. PLoS One. 2019;14: e0217386. doi:10.1371/journal.pone.0217386

7. Siramaneerat I, Agushybana F, Meebunmak Y. Maternal risk factors associated with low birth weight in Indonesia. Open Public Health J. 2018;11: 376-383. doi:10.2174/1874944501811010376

8. Nurrizka RH, Wahyono TYM. Disparitas Kematian Maternal di Indonesia: Studi Ekologi dengan Analisis Spasial. Media Kesehat Masy Indones. 2018;14: 119-127. doi:10.30597/mkmi.v14i2.3630

9. Pratiwi NL, Fitrianti Y, Nuraini S, Rachmawati T, Laksono AD, Afreni M, et al. Concealed Pregnant Women or Kemel of Gayo Ethnic in Blang Pegayon District, Gayo Lues District, Aceh. Bull Heal Syst Res. 2019;22: 81-90. doi:10.22435/hsr.v22i2.1693

10. Laksono AD, Soerachman R, Angkasawati TJ. Case Study of Muyu Ethnic's Maternal Health in Mindiptara District-Boven Digoel (Studi Kasus Kesehatan Maternal Suku Muyu di Distrik Mindiptana, Kabupaten Boven Digoel). J Reprod Heal. 2016;07/03: 145-155. doi:10.22435/kespro.v7i3.4349.145-155

11. Kurniati A, Chen C-M, Efendi F, Elizabeth Ku L-J, Berliana SM. Suami SIAGA: Male 
engagement in maternal health in Indonesia. Health Policy Plan. 2017;32: 1203-1211. doi:10.1093/heapol/czx073

12. Rumaseuw R, Berliana SM, Nursalam N, Efendi F, Pradanie R, Rachmawati PD, et al. Factors Affecting Husband Participation in Antenatal Care Attendance and Delivery. IOP Conference Series: Earth and Environmental Science. 2018. p. 116. doi:10.1088/1755-1315/116/1/012012

13. Mmusi-Phetoe RMM. Social Factors Determining Maternal and Neonatal Mortality in South Africa: A Qualitative Study. Curationis. 2016;39: 8. doi:10.4102/curationis.v39i1.1571

14. Laksono AD, Paramita A, Wulandari RD. Socioeconomic Disparities of Facility-Based Childbirth in Indonesia. Int Med J. 2020;25: 291-298.

15. Tripathi V, Singh R. Regional differences in usage of antenatal care and safe delivery services in Indonesia: Findings from a nationally representative survey. BMJ Open. 2017;7. doi:10.1136/bmjopen-2016-013408

16. Efendi F, Sebayang SK, Astutik E, Hadisuyatmana S, Has EMM, Kuswanto H. Determinants of safe delivery utilization among Indonesian women in eastern part of Indonesia. F1000Research. 2020;9: 332. doi:10.12688/f1000research.23324.1

17. Wulandari RD, Laksono AD, Nantabah ZK. Effect of Marital Status on Completeness of Antenatal Care Visits among Childbearing Age Women in Rural Indonesia. MedicoLegal Updat. 2020;20: 1432-1437.

18. Tokhi M, Comrie-Thomson L, Davis J, Portela A, Chersich M, Luchters S. Involving Men to Improve Maternal and Newborn Health: A Systematic Review of The Effectiveness of Interventions. PLoS One. 2018;13: e0191620. doi:10.1371/journal.pone.0191620

19. Sharma V, Leight J, Giroux N, Abdulaziz F, Nyqvist MB. "That's a woman's problem": A qualitative analysis to understand male involvement in maternal and newborn health in Jigawa state, northern Nigeria. Reprod Health. 2019;16: Article number 143. doi:10.1186/s12978-019-0808-4

20. Zaman SB, Gupta RD, Al Kibria GM, Hossain N, Bulbul MMI, Hoque DME. Husband's involvement with mother's awareness and knowledge of newborn danger signs in facility-based childbirth settings: A cross-sectional study from rural Bangladesh. BMC Res Notes. 2018;11: Article number 286. doi:10.1186/s13104-018-3386-6

21. Chikalipo MC, Chirwa EM, Muula AS. Acceptability of Couple Antenatal Education: A Qualitative Study of Expectant Couples Attending Antenatal Clinics In Blantyre, Malawi. Malawi Med J. 2018;30: 146-151. doi:10.4314/mmj.v30i3.3

22. Yusuf M, Kodhiambo M, Muendo F, Kariuki J. Determinants of Access to Skilled Birth Attendants by Women in Galkacyo District, Somalia. Asian J Med Heal. 2017;4: 1-9. doi:10.9734/ajmah/2017/32364

23. Sharma V, Leight J, AbdulAziz F, Giroux N, Nyqvist MB. Illness Recognition, Decision Making, and care Seeking for Maternal and Newborn Complications: A Qualitative Study in Jigawa State, Northern Nigeria. J Heal Popul Nutr. 2017;36: 46. doi:10.1186/s41043-017-0124-y

24. Triratnawati A. Patterns of Antenatal Care and Health Seeking Behavior for Pregnant Women, Mbojo Tribe, Bima, West Nusa Tenggara (Pola Antenatal Care dan Health Seeking Behavior Ibu Hamil Suku Mbojo, Bima, Nusa Tenggara Barat). MOZAIK Hum. 2018;18: 33-49. doi:10.20473/mozaik.v18i1.9884

25. Suhandjati S. Male Leadership in the Family: Its Implementation in Javanese Society (Kepemimpinan Laki-laki Dalam Keluarga: Implementasinya pada Masyarakat Jawa). THEOLOGIA. 2018;28: 329-350. doi:10.21580/teo.2017.28.2.1876

26. National Population and Family Planning Board, Statistics Indonesia, Ministry of 
Health, The DHS Program. The 2017 Indonesia Demographic and Health Survey. Jakarta; 2018. Available: https://www.dhsprogram.com/pubs/pdf/FR342/FR342.pdf

27. Omar F, M OK, Musili F. Socio-Demographic and Economic Factors Associated With ANC Attendance Among Women of Reproductive Age. J Heal Med Nurs. 2020;5: 4859. Available: https://www.iprjb.org/journals/index.php/JHMN/article/view/1053

28. Shibre G, Zegeye B, Idriss-Wheeler D, Ahinkorah BO, Oladimeji O, Yaya S. Socioeconomic and Geographic Variations In Antenatal Care Coverage In Angola: Further Analysis of The 2015 Demographic And Health Survey. BMC Public Health. 2020;20: Article number 1423. doi:10.1186/s12889-020-09320-1

29. Wulandari RD, Putri NK, Laksono AD. Socioeconomic Disparities in Antenatal Care Utilisation in Urban Indonesia. Int J Innov Creat Chang. 2020;14: 498-514.

30. Obasohan DN, Karo HA, Obasohan PE. Socioeconomic and Demographic Barriers To Assessing Ante Natal Care Services Among Women of Child Bearing Age In Wushishi Local Government Area, Niger State, Nigeria. World J Pharm Res. 2017;7: 1264-1271. doi:10.20959/wjpr20181-10220

31. Teklesilasie W, Deressa W. Barriers to husbands' involvement in maternal health care in Sidama zone, Southern Ethiopia: A qualitative study. BMC Pregnancy Childbirth. 2020;20: 1-8. doi:10.1186/s12884-019-2697-5

32. Utami EG, Abdiana A, Nurdiyan A. Factors Associated with Antenatal Care Visits at District Of Sungayang Health Center, Tanah Datar Regency In 2017. J Midwifery. 2017;2: 26-34. doi:10.25077/jom.2.1.26-34.2017

33. Maken ZH, Nasir Idrees I, Zahid A, Zulfiqar A, Munib A, Hassan F, et al. Factors influencing father's antenatal and perinatal involvement in maternal health care. $\mathrm{J}$ Matern Neonatal Med. 2018;31: 2569-2575. doi:10.1080/14767058.2017.1347920

34. Hamed AF, Roshdy E, Sabry M. Egyptian Status of Continuum of Care for Maternal, Newborn, and Child Health: Sohag Governorate As An Example. J Med Sci Public Heal. 2018;7: 417-426. doi:10.5455/ijmsph.2018.0102607032018

35. Othman S, Almahbashi T, Alabed AAA. Factors Affecting Utilization Of Antenatal Care Services In Sana'a City, Yemen. Malaysian J Public Heal Med. 2017;17: 1-14. doi:10.37268/mjphm/vol.17/no.3/art.230

36. Chanda SK, Ahammed B, Howlader MH, Ashikuzzaman M, Shovo T-E-A, Hossain MT. Factors Associating Different Antenatal Care Contacts of Women: A CrossSectional Analysis of Bangladesh Demographic and Health Survey 2014 Data. PLoS One. 2020;15: e0232257. doi:10.1371/journal.pone.0232257

37. Fagbamigbe AF, Idemudia ES. Wealth and antenatal care utilization in Nigeria: Policy implications. Health Care Women Int. 2016;38: 17-37. doi:10.1080/07399332.2016.1225743

38. Wulandari RD, Laksono AD. Is parity a predictor of neonatal death in Indonesia? Analysis of the 2017 Indonesia demographic and health survey. Indian J Forensic Med Toxicol. 2020;14: 2161-2166. 
Figures

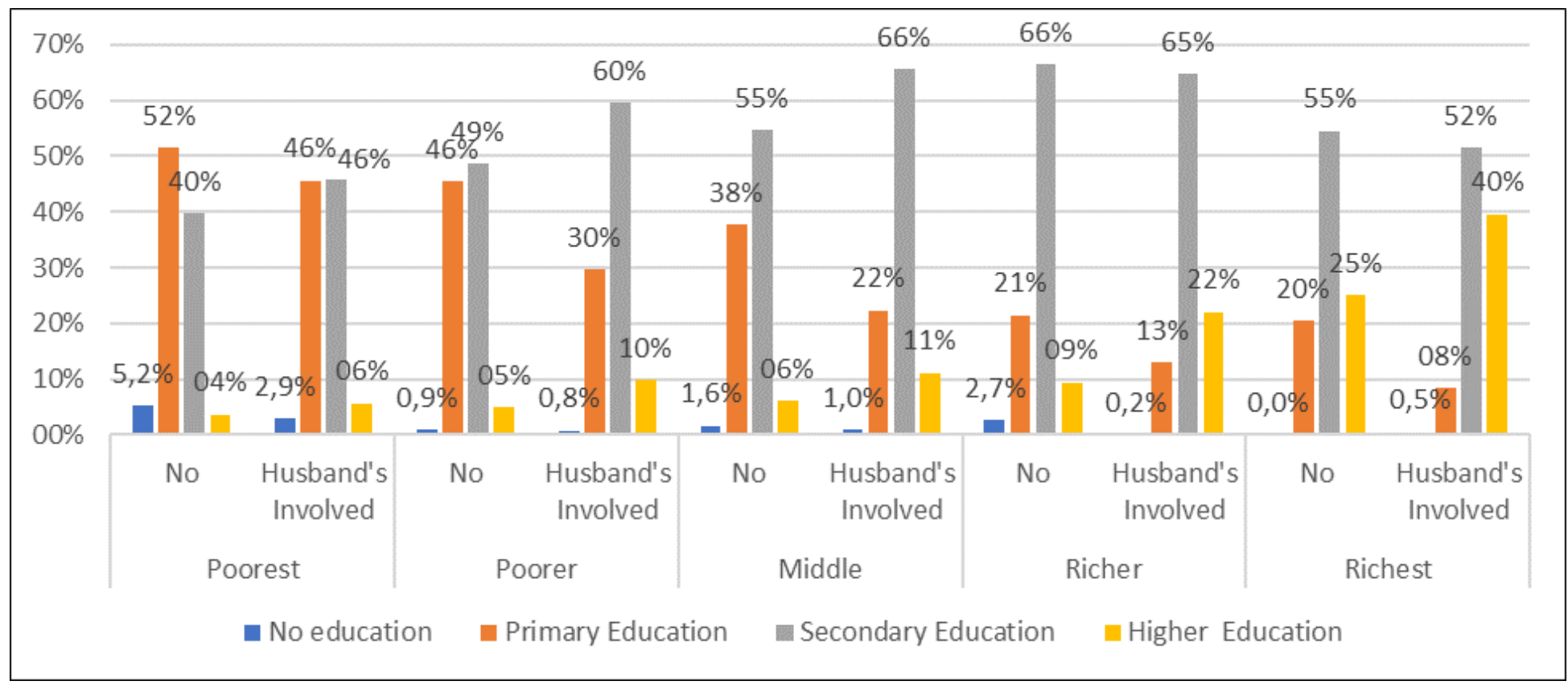

Figure 1

Interaction diagram between wealth status, education level, and husband's involvement in ANC in rural Indonesia $(n=7,156)$ 